УДК 316.346 .32

Клименко, О. Ю. (2020). Вербування та експлуатація дівчат під час збройних конфліктів (досвід Донбасу). Сочіологічні студї, 2 (17), 66-75. DOI: 10.29038/2306-3971-2020-02-66-75

\title{
Вербування та експлуатація дівчат під час збройних конфліктів (досвід Донбасу)
}

\author{
Олена Клименко - \\ доктор соиіологічних наук, \\ доиент, професор кафедри \\ економіки, підприємництва \\ та соиіальних технологій, \\ Державний університет \\ телекомунікацій, Киї, Украӥна
}

\author{
Elena Klymenko - \\ PhD in Sociology, Professor \\ at the Department of Economics, \\ Entrepreneurship and Social \\ Technologies, State University \\ of Telecommunications, Kyiv, \\ Ukraine \\ E-mail: klimenkoelens@gmail.com \\ ORCID: https://orcid.org/0000-0002- \\ $8560-8642$
}

DOI: 10.29038/2306-3971-2020-0266-75

Reseived: November, 2020

$1^{\text {st }}$ Revision: November, 2020

Accepted: December, 2020

Мета статті - вивчення проблеми залучення дітей до участі у військових конфліктах й аналіз досвіду Донбасу в питанні вербування дівчат до незаконних збройних формувань та їх опосередкованої участі (експлуатації військовими) в позабойовому житті. Оскільки ця проблема недостатньо досліджена, зроблено спробу аналізу добровільних і примусових форм вербування дівчат, ролі в цьому пропаганди в 3MI, соціальних та Інтернет-мереж, а також учителів загальноосвітніх шкіл і безпосередньо батьків. Окремо проведено аналіз факторів, що сприяють залученню дівчат як специфічної гендерної групи до участі в діяльності незаконних збройних формувань. Особливу увагу приділено висвітленню факторів соціального відчуження та тяжіння в рамках негативної взаємодії, а також вивченню особистісних і групових мотивів приєднання дівчат до незаконних збройних угрупувань. Окремо досліджено роль віртуальної взаємодії в процесі вербування.

Klymenko Elena. Recruitment and Exploitation of Girls During Armed Conflicts (Donbass Experience). The purpose of the article is to study the problem of attracting children to participate in military conflicts, as well as to analyze the experience of Donbass in the issue of involving girls in the activities of illegal armed formations and their indirect participation (exploitation by the military) outside of combat life. Since this problem has not been sufficiently studied by the author, an attempt was made to analyze voluntary and compulsory forms of recruiting girls and the role of propaganda in the media, social and Internet networks, as well as teachers of secondary schools and parents directly in this. A separate analysis of the factors contributing to the attraction of girls, as a specific gender group, to participate in the activities of illegal armed groups is carried out. Particular attention is paid to highlighting the role of factors of social alienation and attraction in the framework of the negative experience of social interaction, in addition, the personal and group motives of girls joining illegal armed groups are studied. A key role in the formation of strategies for attracting girls to join militarypatriotic clubs and armed groups in the Donbas is the determination of the individual characteristics of social interaction carried out by a child. The experience of negative social interaction with the immediate environment plays a fundamental role in the process of accepting consent. That is why the article analyzes the dependence of the choice of recruitment strategies for adolescent girls on the factors of social alienation and attraction of those present in their lives.

Key words: children, girls, armed conflict, recruitment, exploitation, illegal armed groups.

Клименко Елена. Вербовка и эксплуатация девушек во время вооруженных конфликтов (опыт Донбасса). Цель статьи - изучение проблемы привлечения детей к участию в военных конфликтах, а также анализ опыта Донбасса в вопросе вовлечения девушек в деятельность незаконных вооруженных формирований и опосредованное их участие (эксплуатации военными) во внебоевой жизни. Поскольку данная проблема недостаточно исследована, нами предпринята попытка анализа добровольных и принудительных форм вербовки девушек и роли в этом пропаганды в СМИ, социальных и Интернет-сетей, а также учителей общеобразовательных школ и непосредственно родителей. Отдельно проводится анализ факторов, способствующих привле- 
чению девушек как специфической гендерной группы к участию в деятельности незаконных вооруженных формирований. Особое внимание уделяется освещению роли факторов социального отчуждения и притяжения в рамках негативного опыта социального взаимодействия, кроме того, изучены личностные и групповые мотивы вступления девушек в незаконные вооруженные группировки.

Ключевую роль при формировании стратегий привлечения девушек к вступлению в военно-патриотические клубы и вооруженные группировки на Донбассе играет определение индивидуальных особенностей социального взаимодействия, осуществляемого ребенком. Фундаментальную роль в процессе принятия согласия играет опыт негативного социального взаимодействия с ближайшим окружением. Именно поэтому в статье анализируется зависимость выбора стратегий вербовки девочек-подростков от факторов социального отчуждения и притяжения, присутствующих в их жизни.

Ключевые слова: дети, девушки, вооруженный конфликт, вербовка, эксплуатация, незаконные вооруженные формирования.


збройних конфліктів проживало 426 млн дітей. За шість місяців 2020 р. цей показник сягнув 415 млн. Така динаміка свідчить про збільшення до абсолютно рекордних показників кількості неповнолітніх, дитинство яких протікає в умовах війни до кінця поточного року. Ці вражаючі цифри оприлюднені в листопаді 2020 р. благодійною асоціацією Save the Children, яка підготувала щорічний світовий моніторинг проживання дітей в умовах збройних конфліктів. Відповідно до офіційної доповіді «Війна проти дітей» за 2019 р. кількість дітей, котрі ростуть у зонах бойових дій, збільшилася на 11 млн, порівняно з попереднім роком. Отже, майже кожна п'ята дитина у світі проживає в умовах збройних конфліктів (Stop the War on Children, 2020a, 2020b).

Також зазначено, що за останні десять років (із 2010 р.) у світі вбито або покалічено понад 93 тис. дітей. У минулому році Організація Об’єднаних Націй задокументувала 10300 таких випадків. Серед злочинів проти дітей найбільш розповсюдженими визначено залучення до участі в збройних угрупованнях і сексуальне насильство. Найнебезпечнішими країнами для дітей у минулому році стали Афганістан, Демократична Республіка Конго, Ірак, Смен, Малі, Нігерія, Сирія, Сомалі, Судан, Південний Судан і Центрально-Африканська Республіка (Stop the War on Children, 2020a, p. 12). Міжнародні експерти зазначають, що пандемія, пов'язана з розповсюдженням COVID-19, лише погіршила ситуацію через зростання бідності та перевантаження систем охорони здоров'я. Однак соціальні впливи коронавірусу ще не підраховані.

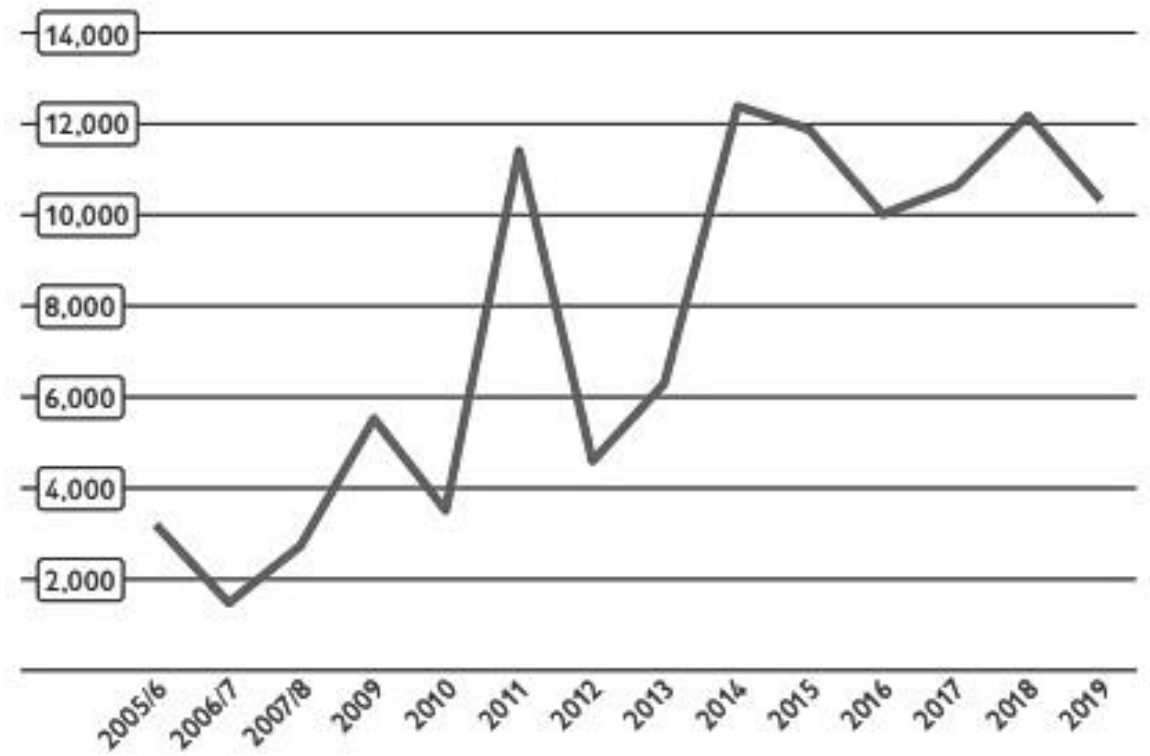

Рис. 1. Динаміка вбивств та каліцтв дітей у збройних конфліктах за останні 15 років (Stop the War on Children, 2020b, p. 12)

Україна у 2020 р. (уперше з 2014 р.) не ввійшла до переліку найбільш небезпечних для дітей країн, однак питання припинення збройного конфлікту на Донбасі залишилося не вирішеним, а отже, ризики 
та загрози життю неповнолітніх, які проживають у зоні проведення бойових дій, залишаються реальними.

За даними ЮНІСЕФ, на кінець 2019 р. за п’ять років війни на Сході України пошкоджено або зруйновано 750 навчальних закладів (школи та дитячі садки), 147 неповнолітніх загинули (98 хлопців і 49 дівчат), 392 дитини отримали поранення - близько 60 \% випадків загибелі (92 особи) або поранення (236 осіб) серед дітей відбулися в результаті артилерійських обстрілів і застосування стрілецької зброї та легких озброєнь. Від вибухів мін постраждало 175 дітей (39 загиблих і 136 поранених), що становить 32,4 \% утрат. У результаті інших інцидентів, пов'язаних із конфліктом, або коли точні причини поки що не встановлені, 6,7 \% дітей загинуло (16 осіб) та отримали поранення (20 осіб). У цьому році моніторинговою місією ООН офіційно зафіксовано 36 обстрілів шкіл на Донбасі (Щонайменше 147 дітей..., 2020).

Значні втрати серед цивільного населення не єдина проблема військово-політичного конфлікту на Сході України. Одним із найгостріших питань сьогодення є ідеологічний вплив на підростаюче покоління, що з тих чи інших причин вимушене перебувати на тимчасово окупованих територіях Донбасу. Найчастіше він здійснюється шляхом вербування дітей до військово-патріотичних формувань, що в перспективі матиме серйозні соціальні наслідки та створюватиме перешкоди для інтеграції регіону в Україну.

Аналіз основних досліджень цієї проблеми (теоретичні засади дослідження, методологія та характеристика емпіричної бази). На жаль, у вітчизняній історіографії відсутні дослідження гендерних аспектів залучення дітей до участі в бойових діях на Донбасі на боці незаконних збройних формувань. У «Соціологічних студіях» автором уже піднімалося питання актуальності вивчення проблеми участі дітей-комбатантів та дітей-солдатів у військово-політичному конфлікті на Сході України (Клименко, 2019а). Однак аналіз наукового доробку американських, ізраїльських і турецьких колег дав змогу виявити разючу схожість вербувальних технологій у діяльності таких радикальних фундаменталістських організацій (визнаних терористичними на міжнародному рівні), як «Ісламська держава», «Джабхат ан-Нусра», «Аль-Каїда», «Талібан» і т. ін. Незважаючи на разючу відмінність, у них надзвичайно схожі програми роботи 3 дітьми та молоддю: від ідеологічної «обробки», вербування до підготовки для прямої участі в бойових діях, здійснення терористичних актів і диверсій. Як і радикальні ісламістські угруповання в Сирії та Іраку, окупаційна терористична влада в Донбасі (за потужного технічного й організаційного сприяння РФ) здійснює піратське теле- й радіомовлення, створює та адмініструє сторінки в Інтернеті, записує й поширює аудіо- та відеозвернення до громадян тощо. Тому міжнародний науковий досвід вивчення зазначеної проблеми може бути в нагоді.

Акцентовано увагу на американському науковому доробку соціологічного аналізу проблем вербування дітей в країнах Близького Сходу. Так, Брюс Хоффман розкриває прямі й латентні механізми залучення дітей до терористичної діяльності (Хоффман, 2003).

Важливе місце серед досліджень стосовно інтернеткомунікацій, які пов’язані 3 діяльністю політичних організацій, займає робота Гілберта Рамсея «Культура джихаду у всесвітній павутині», де розкрито питання негативних впливів на дітей і молодь в Інтернет-мережі. Вона, крім того, цікава детальним аналізом стратегічних прийомів вербування, які у своїх практиках використовують крайні екстремісти (Ramsay, 2013).

На особливу увагу заслуговує колективна робота «Про роль гендерного фактора в запобіганні насильницького екстремізму і радикалізації, що ведуть до тероризму, а також в боротьбі 3 цією загрозою», підготовлена колективом авторів із відділу по боротьбі з тероризмом (ОБТ) Департаменту 3 протидії транснаціональним загрозам (ДТУ) ОБСЕ під керівництвом Камілли Богнамі, у якій висвітлено саме гендерні особливості залучення до незаконних збройних формувань (О роли гендерного фактора, 2016).

Жертвами агітаційних впливів та експлуатації на окупованих територіях «ДНР» ризикують стати всі без винятку діти, однак особливе занепокоєння в сучасному контексті стратегій ведення збройних конфліктів викликають масштаби вербування дівчат. До того ж причини їх вступу або участі в збройних формуваннях часто залишаються поза увагою не лише науковців, а й представників гуманітарних місій. У журналі «Osteuropa» О. Клименко зробила спробу висвітлити 
зазначену проблему в контексті агресивних впливів представників незаконних збройних формувань із використанням російської пропаганди (Klymenko, 2019b).

Дослідження зазначених питань в Україні ускладнене тривалістю військово-політичного конфлікту і його незавершеністю. На окуповані території можуть потрапити лише представники миротворчих місій та гуманітарних організацій, тому інформація, яку ми маємо щодо перебігу подій, отримується виключно з альтернативних джерел (наприклад організації Save the Children, «Рятуємо дітей») та може бути суперечливою й суб'єктивною. Одним із найбільш надійних джерел $є$ статистичні звіти Інституту дослідження проблем світу в Осло, який спеціалізується на дослідженнях «зон конфліктів» та «районів, яких конфлікти торкнулись» (PRIO - Peace Research Institute in Oslo) (Stop the War on Children, 2020a, 2020b).

На окрему увагу заслуговують матеріали за результатами журналістських розслідувань, котрі оприлюднюють окремі факти правопорушень та злочинів, скоєних проти дітей на окупованих територіях Донбасу.

Методологічна база статті включає кількісну і якісну систематизацію даних, представлених 3МI, опрацювання результатів моніторингів міжнародних недержавних організацій, нормативних документів законодавчих органів і міністерств виконавчої влади, вторинний аналіз соціологічних досліджень, проведених іншими дослідницькими іноземними агентами, які $є$ у вільному доступі в мережі Інтернет. Зокрема, використовуються результати соціологічних досліджень:

1. Матеріали, наведені Uppsala Conflict Data Programme (UCDP) «Упсальською програмою даних про конфлікти», провідним світовим постачальником статистичних показників організованого насилля. Її особливістю $є$ наведення кількісної інформації щодо аналізу соціальних проблем зареєстрованих конфліктних подій в усьому світі, починаючи з 1990 по 2019 р.;

2. Оновлені дані про населення Gridded Population of the World i OOH з оцінкою кількості дітей в усьому світі, які проживають в епіцентрі та в безпосередній близькості від бойових дій;

3. Аналітичні звіти щодо перебігу подій у зонах збройних конфліктів міжнародної організації Save the Children «Рятуємо дітей», які здійснюють моніторинг військових злочинів щодо порушення прав дітей у контексті їх рекрутингу до незаконних військових формувань і насилля над ними;

4. Статистичні звіти Peace Research Institute in Oslo «Інституту дослідження проблем світу в Осло», який спеціалізується на вивченні соціальних та правових проблем, які виникають у дітей у «зонах конфліктів» і «районах, яких конфлікти торкнулись».

Тому на сьогодні вкрай актуальні для розширення наукового знання й вивчення факторів, що сприяють вербуванню дітей, аналіз моделей залучення дівчат до незаконних збройних формувань i висвітлення найбільш поширених способів їх експлуатації в збройному конфлікті на Сході України.

Мета статті - дослідити досвід Донбасу з проблеми вербування дівчат до незаконних збройних формувань та опосередкованої їх участі (експлуатації військовими) у збройному конфлікті.

Виклад основного матеріалу й обгрунтування отриманих результатів дослідження. Незаконні збройні угрупування самопроголошених республік «ДНР» i «ЛНР» із самого початку військовополітичного конфлікту на Донбасі активно вербують дітей, оскільки їх участь має низку стратегічних переваг. Наприклад, діти обходяться дешевше, вони можуть бути ефективнішими в стратегічному плані й мають особливу пропагандистську цінність. Дітей вербують як у примусовому, так і в добровільному порядку, через членів сім'ї й лідерів громад, за допомогою пропаганди в ЗМI, у мережі Інтернет та в школах, за безпосередньої участі вчителів або шляхом економічного тиску з боку їхніх сімей. Однак, незалежно від застосовуваного методу, процес вербування не може розглядатися як справді добровільний. Дітей використовують для виконання допоміжних функцій та участі в активних бойових діях у ході збройного конфлікту або як виконавців терористичних актів чи диверсій. Зазвичай, виконання всіх цих функцій супроводжується застосуванням насильства у ставленні до дітей у різних формах. Усе частіше об'єктами вербування стають дівчата, і фактори, що сприяють їх залученню до участі в незаконних збройних угрупуваннях, можуть бути іншими, ніж у хлопчиків.

На початок 2020 р., за результатами слідчих дій, проведених Службою безпеки України, офіційно доведено існування та протизаконну діяльність двох військово-патріотичних клубів «Спартанці» та «Амазонки», створених верхівкою збройного угруповання «ДНР» за безпосередньої підтримки та 
керівництва представників окупаційного контингенту Збройних сил Російської Федерації в Донецькій області. Основна мета зазначених організацій - вербування хлопчиків і дівчат до участі в так званому «військово-патріотичному русі» «Молода гвардія», який із 2015 р. діє на окупованій території Донбасу (ГПУ, 2019).

Основними завданнями таких об’єднань є вербування та залучення малолітніх і неповнолітніх осіб до участі в протиправній терористичній діяльності «ДНР» під виглядом військово-патріотичного навчання, виступів на різних військово-спортивних заходах і виховання соціально-свідомих громадян. Слідчими Генеральної прокуратури України встановлено, що підозрювані вербували дітей і підлітків у віці 5-18 років для підготовки до участі в бойових діях проти сил АТО/ООС.

Обов'язковою умовою членства в клубах $є$ носіння камуфляжу із символікою угруповання «ДНР». Дітей навчали поводження зі зброєю, боєприпасами та вибухівкою, що суперечить ключовим положенням міжнародної конвенції «Про захист прав дітей», зокрема, ст. 2 та ст. 4 факультативного протоколу до Конвенції про права дітей, який стосується участі дітей в збройних конфліктах (Конвенція, 1989). Окрім того, така активна діяльність представників незаконних збройних формувань порушує ст. 77 Додаткового протоколу до Женевських конвенцій від 12 серпня 1949 року, що стосується захисту жертв міжнародних збройних конфліктів та ст. 3 Конвенції про заборону та негайні заходи щодо ліквідації найгірших форм дитячої праці 1999 р., а також ст. 8 Римського статуту Міжнародного кримінального суду 1998 р., ст. 2 Конвенції про захист прав дитини 1989 р. У Конституції України ст. 52 ст. передбачено, що «будь-яке насильство над дитиною та ії експлуатація переслідуються за законом» (Конституція України, 1996), а ст. 30 Закону України «Про охорону дитинства» категорично забороняє участь дітей у воєнних діях і збройних конфліктах (Про охорону дитинства, 2001). Однак ні міжнародні норми, ні положення українського законодавства не перешкоджають вербуванню та експлуатації неповнолітніх на окупованих територіях Донбасу. На нашу думку, цікавим $є$ факт гендерного поділу під час формування клубів, що може свідчити про наявність різних стратегій пропагандистських впливів на свідомість хлопців та дівчат, а отже, й існування особливих (статевих) маркерів формування соціальної взаємодії.

Проблема вербування дівчат до незаконних збройних формувань та опосередкованої їх участі в збройному конфлікті

Світовий досвід збройних конфліктів дає можливість говорити про існування цілого комплексу передумов, за якими дівчатка є кращими об'єктами вербування. По-перше, це привернення уваги широкої громадськості: напади, що здійснюються дівчатами, особливо підлітками, мають більш високу пропагандистську цінність, оскільки залучають пильнішу увагу засобів масової інформації, ніж учать у збройному конфлікті хлопців-комбатантів.

По-друге, сучасні комунікаційні стратегії свідчать, що залучення до військових формувань представниць жіночої статі сприяє гендерній «нормалізації» малої групи, підвищує ії соціальну привабливість для майбутніх новобранців і демонструє можливість соціальної взаємодії з протилежною статтю.

По-третє, підвищення ефективності, оскільки дівчата не відповідають традиційним уявленням про загрозу безпеці та викликають менше підозр у військових, то під час їх залучення до бойових дій чи диверсійної роботи збільшується ймовірність успішного виконання військової операції або організації диверсії, зокрема на підготовчому (допоміжному) етапі.

Крім того, аналізуючи залучення представниць жіночої статі до участі в діяльності збройних формувань, можемо виокремити цілий комплекс «рушійних факторів» і «чинників тяжіння».

Отже, рушійними факторами залучення неповнолітніх дівчат до участі в збройному конфлікті $\epsilon$ :

1. Дівчаток можна спонукати «закохатися» в одного з активних членів збройних формувань за допомогою соціальних мереж і втягнути в антисоціальну діяльність із високою метою - допомоги коханій людині досягти якоїсь великої ідеологічної мети. Одним із прикладів реалізації зазначеної стратегії $\epsilon$ зафіксований факт вербування дітей до своїх лав незаконного збройного формування «Бригади Привид» у м. Алчевську Луганської області. У 2015 р. до його лав зараховано Богдану Нещерет, яка писала зворушливі листи одному з провідних терористів I. Гіркуну та зачитувала для свого кумира в ефірі одного з російських пропагандистських каналів (Зубченко, 2016).

2. Перспектива вийти заміж за учасника збройного конфлікту може бути розглянута дівчатамипідлітками як варіант порятунку від структурного насильства 3 боку батьків та шанс розпочати 
самостійне життя поза неблагополучною сім'єю. Цей варіант був досить розповсюдженим у 20142015 рр. на Донбасі. Так, у Луганській області середній вік жінок, які брали шлюб, суттєво зменшився з 25,6 років у 2013 р. на 22,5 років у 2014 р. й опустився до віку 20,7 років у 2015 р. (Чеботарьова, Бахмут, 2016). Водночас кількість розлучень збільшилась удвічі.

3. У мережі Інтернет існують спеціальні чати й форуми лише для «патріотично налаштованих» жінок, у яких активно комунікують професійні психологи, представниці слабкої статі, їх основною метою є вербування дівчат шляхом демонстрації їм привабливості військово-патріотичної діяльності. Так, у травні 2015 р. в Інтернет-мережі з'явилося відео тренування членів дитячого клубу «Вітязь», організованого представниками незаконних збройних формувань «ДНР» у м. Амвросіївка Донецької області, у якому був сюжет про військові змагання між дівчатами та хлопцями «Child Warriors of Donetsk» (Діти-воїни Донецька), зняте знімальною групою «Vice News» (Зубченко, 2016). Юні представниці жіночої статі продемонстрували більшу майстерність, ніж юнаки, та перемогли, а жіночий голос за кадром активно коментував сюжет та заохочував дівчат до вступу в організацію.

4. Не треба забувати й про існування традиційних, випробуваних часом форм, зокрема таких, як сексуальне насилля, у ставленні до дівчат у ситуаціях взаємодії збройних угрупувань із цивільним населенням. У деяких випадках більшість згвалтованих дівчат потрапляють у сексуальне рабство. Сексуальне насильство як тактика тероризму було прямо засуджено в резолюціях Ради Безпеки ООН, однак продовжує активно застосовуватись у збройних конфліктах. На сьогодні акти сексуального насильства та насильства на гендерному грунті використовуються як інструмент посилення влади незаконних військових формувань на окупованих територіях. У 2019 р. на непідконтрольній Україні території зафіксовано 550 фактів скоєння кримінальних злочинів «проти статевої свободи та недоторканості дітей», з яких 148 - згвалтування. За статистичними даними правоохоронних органів це вдвічі більше, ніж у 2018 р. (У 2019 зареєстровано, 2020).

Наслідком пережитого в дитинстві насильства може бути неповноцінний особистісний, інтелектуальний і соціальний розвиток. Воно не лише завдає значної шкоди окремій дитині, а й призводить до суттєвих соціальних утрат для суспільства в цілому. При тому що насильство може бути не тільки сексуальним, а й набувати іншої форми, однак вони часто взаємопов'язані. Якщо подолання конкретних явищ, таких як вербування й експлуатація дітей, вимагає застосування адресних підходів соціальної протидії, то заходи попередження наслідків насильства можуть дати результат лише в тому випадку, якщо вони спираються на комплексну стратегію запобігання зазначеному явищу в цілому серед комбатантів та солдатів.

Ключову роль у формуванні стратегій залучення дівчат до вступу у військово-патріотичні клуби та збройні угрупування відіграє врахування індивідуальних особливостей соціальної взаємодії дитини. Особисті труднощі й інші мотиви, безумовно, роблять ії вразливою до актів вербування. Незважаючи на це, радикалізація рідко відбувається поза реаліями соціального життя дівчини-підлітка. Фундаментальну роль у процесі прийняття згоди відіграє досвід негативної соціальної взаємодії з найближчим оточенням.

Таблиия 1

Фактори соціального відчуження та тяжіння, сформовані в рамках негативного досвіду соціальної взаємодії, які впливають на успіх вербування

\begin{tabular}{|l|l|}
\hline \multicolumn{1}{|c|}{ Фактор соціального відчуження } & \multicolumn{1}{c|}{ Фактор соціального тяжіння } \\
\hline Відсутність особистої свободи дій & Схильність до впливу пропаганди \\
\hline Відсутність мети або сенсу в житті & Сподівання на соціальний захист \\
\hline Відсутність безпеки або стабільності & Наявність радикалізованого члена сім'ї \\
\hline Незрозумілий правовий статус & Участь у злочинній групі \\
\hline Погані стосунки з родиною та (або) друзями & Досвід фізичного та (або) морального насильства \\
\hline Досвід домашнього насильства & Прагнення до слави, мученицької смерті \\
\hline Відчуття несправедливості & Схильність до насильства \\
\hline
\end{tabular}

Крім того, треба враховувати, що розробка стратегії вербування безпосередньо залежить від певних факторів соціального відчуження й тяжіння, які впливають на вибір моделей впливу на дитину: використання найближчого оточення, соціальних мереж, віртуального середовища, ресурсів ЗМI, 
наочних зразків та ін. Зазначені в табл. 1 фактори негативної соціальної взаємодії формують так звані чинники тяжіння неповнолітніх до вступу у військово-патріотичні клуби й збройні угрупування.

Аналізуючи досвід дітей окупованих територій Донбасу, нам удалося виділити «макро-» та «мікрорівні» мотивації дітей до участі в збройному конфлікті, відповідно до глибини впливу вербувальників на процеси соціалізації.

На макрорівні так звані «агітатори» 3-поміж підготовлених та досвідчених представників незаконних збройних формувань, застосовуючи ідеологічні конструкти, намагаються зайняти місце первинних агентів соціалізації, витіснивши батьків та друзів, маніпулюючи стратегічними потребами дитини (справжні друзі - це побратими по зброї, зможеш самостійно себе забезпечувати, друзі будуть заздрити й ін.).

На мікрорівні потужними мотиватором є прагнення дитини радикально змінити своє життя через наявність особистого травматичного досвіду соціальної взаємодії. Потенційних членів для збройних формувань із традиційного повсякденного життя «виштовхує» в ці групи їхня власна особиста історія, історія їхньої сім'і, історія їхніх стосунків із найближчим оточенням. Під час вербування дівчат із мотивацією мікрорівня найчастіше «приваблюють» розповіді про легендарне життя «справжніх героїв», які, незважаючи на труднощі та негаразди, змогли стати легендою (як приклад, можна навести міфи про життя й смерть терористів із позивними «Гіві» та «Моторола»).

У деяких випадках існують прямі причинно-наслідкові зв'язки між радикалізацією та наявністю психічного захворювання в дитини, із яким може бути пов'язана низка соціальних ризиків. Це зазвичай активно використовують вербувальники, котрі вважають їх легкою здобиччю й не переймаються наслідками. Під час залучення до участі в бойових діях таких надмірно вразливих дітей, як правило, у них починають прогресувати соціопатія й надмірна фіксація на політичній/релігійній ідеології. Міжнародна практика визначає таке явище терміном «дешевий тероризм».

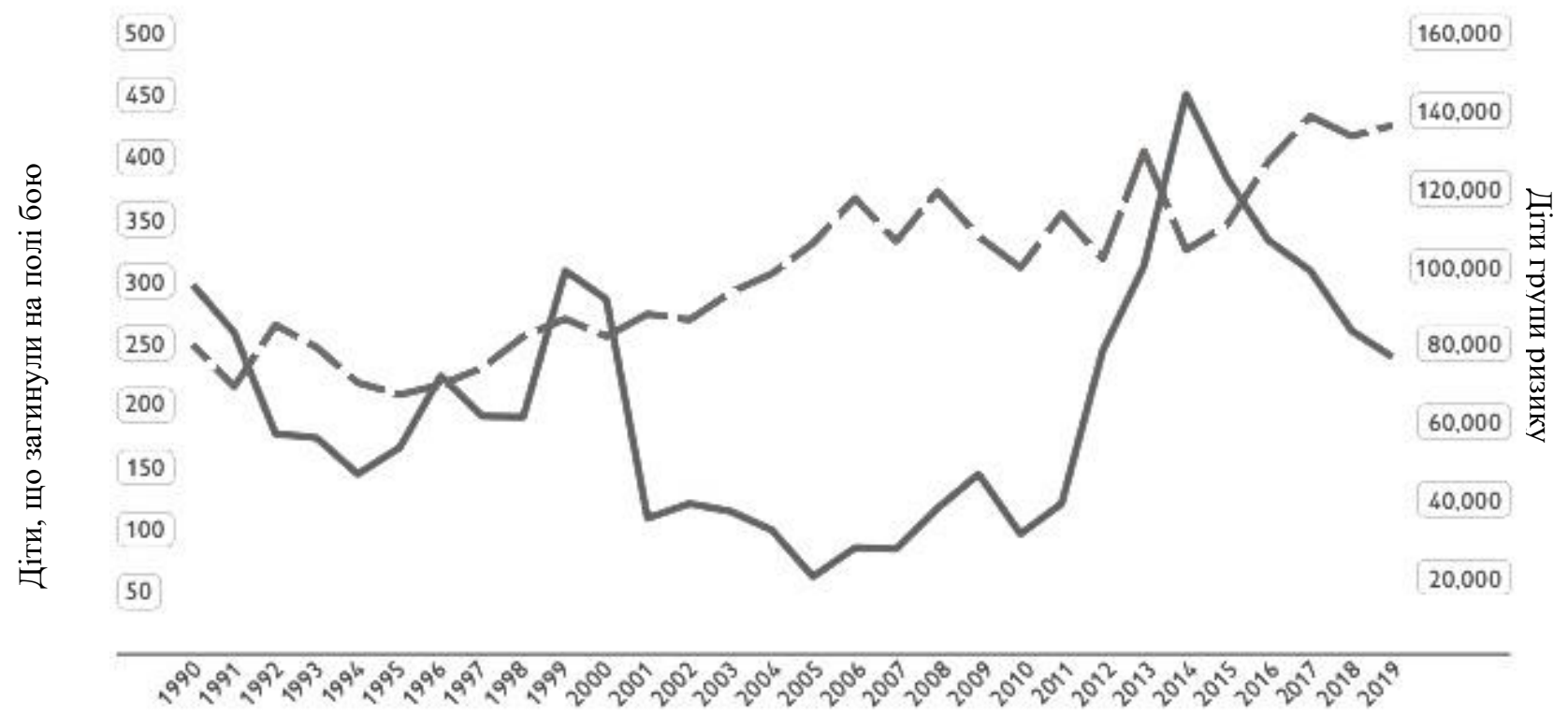

Діти групи ризику (залучені до бойових дій)

Діти, які загинули на полі бою

Рис. 2. Світові показники залучення дітей до участі в бойових діях на бочі збройних формувань та рівень їх загибелі на полі бою (Stop the War on Children, 2020b, p. 20)

Враховуючи той факт, що в дітей процес формування особистості є незавершеним, для більшості 3 них штучно створено певну систему переконань, стає великою місією, яку неповнолітній буде виконувати навіть ціною власного життя, у випадку дітей Донбасу - захист та розповсюдження ідей «русского мира». 
Мотивація може виникати як на індивідуальному, так і на груповому рівнях.

На індивідуальному рівні дитина потребує підтримки особистих прагнень і розширення іiі соціальної мобільності, а тому вважає, що приєднання до певних воєнізованих структур має забезпечити альтернативні можливості для підвищення соціальної значущості. Особливо це актуально для дівчат, які прагнуть бути кращими за інших. Більшість дітей у підлітковому віці, переживаючи факти дорослішання, часто відчувають незадоволеність або розчарування своїм соціальним оточенням, що робить ї уразливими для вербування та маніпулювання. Індивідуальні мотивації складні й варіюються залежно від контексту, походження й демографічної ситуації, хоча загальним мотиватором $\epsilon$ взаємодія з беззаперечною силою, в основу якої покладено спільні світоглядні позиції.

На груповому рівні в основі мотивації - намагання дитини знизити ступінь соціальної несправедливості найбільш примітивним способом - за допомогою фізичного насилля. Для дівчат-підлітків одним із засобів досягнення зазначеної мети $є$ можливість загрози зброєю. Групова мотивація як одна 3 форм колективної взаємодії є важливою складовою частиною набуття дитиною ознак індивідуальної й колективної ідентичності, яка впливає на відносний успіх вербувальних стратегій, заснованих на ідеологічній обробці та грі з патріотичними почуттями.

Отже, розмежування між мотиваціями й пріорітетними цілями терористичних груп має першочергове значення для успішного застосування стратегій ресоціалізаціії дітей із досвідом участі у військово-патріотичних клубах та незаконних збройних формуваннях. Однією зі слабких позицій наукових досліджень у такій царині $\epsilon$ ігнорування статевих і вікових особливостей дітей, які потрапляють під пропагандистські впливи.

Висновки та перспективи подальших досліджень. Увага військових усього світу (незалежно від їх національності, політичних переконань, віросповідання та іншого) до вербування дітей і молоді в лави збройних формувань не є випадковою. Адже цю вікову категорію громадян відрізняє низка соціально-психологічних та ментальних особливостей, які роблять ії надзвичайно сприйнятливою до пропаганди й схильною до маніпулятивних впливів. Ці ж особливості призводять до того, що підлітки можуть легко наслідувати різноманітні негативні приклади девіантної поведінки, проявляючи при цьому жорстокість, яка інколи значно перевершує дорослі аналоги (такі випадки неодноразово фіксувались у світовій практиці міжнародними гуманітарними організаціями).

Отже, ключову роль під час формування стратегій залучення дівчат до вступу у військово-патріотичні клуби та збройні угрупування на Донбасі відіграє врахування індивідуальних особливостей негативного досвіду соціальної взаємодії дитини з найближчим оточенням. Фактори соціального відчуження й тяжіння покладені в основу мотиваційної бази дитини, ключовими складовими частинами якої виступають індивідуальні та групові мотиватори, що діють на «макро-» й «мікрорівнях».

Водночас проблема залучення дівчат до участі в збройних конфліктах є слабодослідженою, гендерні аспекти, зазвичай, ігноруються під час вивчення особливостей участі дітей у бойових діях та аналізу ідеологічних впливів на них. Тому цей аспект соціального життя, пов'язаний із тривалим протіканням військово-політичного конфлікту на Сході України, потребує більш глибокого аналізу й більш детального наукового пошуку.

\section{Джерела та література}

1. ГПУ расследует вербовку детей боевиками «ДНР» (2019). Получено 12 августа 2019 c https://zn.ua/ UKRAINE/gpu-rassleduet-verbovku-detey-boevikami-dnr-326711_.html

2. Зубченко, С. (2016). Дети войны: как Россия привлекает украинскую молодежь с временно оккупированных территорий к террористической деятельности. ZN,UA. 15. Получено 29 апреля $2016 \mathrm{c}$ https://zn.ua/ internal/deti-voyny-kak-rossiya-privlekaet-ukrainskuyu-molodezh-s-vremenno-okkupirovannyh-territoriy-kterroristicheskoy-deyatelnosti-_.html

3. Клименко, О. Ю. (2019a). Залучення дітей до участі у збройних конфліктах: моделі та методи вербування (український досвід). Соціологічні студіï, 2(15), 13-20. DOI: https://doi.org/10.29038/2306-3971-2019-02$13-20$

4. Конвенція про права дитини (1989). Отримано 20 травня $20203 \mathrm{https} / /$ zakon.rada.gov.ua/laws/show/ 995_021\#Text

5. Конституиія Украӥни (1996). Отримано 01 січня 20203 https://zakon.rada.gov.ua/laws/show/254к/96вр\#Text 
6. О роли гендерного фактора в предотвращении насильственного экстремизма и радикализации, ведущих к терроризму, а также в борьбе с этой угрозой (2016). Получено 18 июня $2016 \mathrm{c} \mathrm{https://www.osce.org/}$ files/f/documents/1/1/429452_0.pdf

7. Про охорону дитинства: Закон України (2001). Отримано 03 липня 20203 https://zakon.rada. gov.ua/laws/show/2402-14\#Text

8. У 2019 зареєстровано 148 згвалтувань, у яких потерпілими є неповнолітні (2020). Отримано 30 січня 2020 з https://ua.interfax.com.ua/news/general/638405.html

9. Хоффман, Б. (2003). Терроризм: взгляд изнутри. Получено 14 сентября 2020 с http://library.khpg.org/ index.php?id=1462096486

10. Чеботарьова, М. Н., Бахмут, Ю. О. (2016). Сучасна шлюбна структура населення Луганської області. Економічний вісник Донбасу, 2(44), 4-7. Отримано 22 червня 2016 з http://www.evd-journal.org/download/ 2016/2(44)/pdf/1-Chebotarova.pdf

11. Щонайменше 147 дітей загинуло і 392 були поранені в результаті збройного конфлікту на Донбасі ООН (2020). Отримано 01 червня 2020 з https://www.unn.com.ua/uk/news/1872560-schonaymenshe-147ditey-zaginuli-ta-392-buli-poraneni-v-rezultati-zbroynogo-konfliktu-na-donbasi-oon

12. Klymenko, E. (2019b). Die Schwächsten der Schwachen Ukraine: Kinder im Krieg. Osteuropa, 3-4, $185-191$. Retrieved June 10, 2020 from https://www.zeitschrift-osteuropa.de/hefte/2019/3-4/die-schwaechsten-derschwachen/

13. Ramsay, G. (2013). Jihadi Culture on the World Wide Web. 51-78. https://doi.org/10.5040/9781501301049.ch003. Retrieved October 10, 2020 from https://www.bloomsbury.com/uk/jihadi-culture-on-the-world-wide-web9781441124395/

14. Stop the War on Children. Gender Matters (2020a). Save the Children. Retrieved November 20, 2020 from https://resourcecentre.savethechildren.net/node/16784/pdf/ch1413553.pdf

15. Stop the War on Children. Killed and Maimed: A Generation of Violations Against Children in Conflict (2020b). Save the Children. Retrieved November 20, 2020 from https://resourcecentre.savethechildren.net/node/18486/ pdf/killed_and_maimed_a_generation_of_violations_final.pdf

\section{References}

1. At least 147 children were killed and 392 were injured as a result of the armed conflict in Donbass - UN. (2020) Retrieved June 01, 2020 from https://ultati-zbroynogo-konfliktu-na-donbasi-oonwww.unn.com.ua/ru/news/ 1872560-schonaymenshe-147-ditey-zaginuli-ta-392-buli- poraneni-v-rez

2. Chebotaryova, M., Bakhmut, Y. (2016). Modern marriage structure of the population of Luhansk region. Economic Bulletin of Donbass. 2 (44), 4-7. Retrieved June 22, 2016 from http://www.evd-journal.org/download/ 2016/2(44)/pdf/1-Chebotarova.pdf

3. Convention on the Rights of the Child (1989). Retrieved May 20, 2020 from https://zakon.rada. gov.ua/laws/show/995_021\#Text

4. Hoffman, B. (2003). Terrorism: An Inside Look. Retrieved September 14, 2020 from http://library.khpg.org/ index.php?id=1462096486

5. In 2019, 148 rapes were registered, in which the victims were minors. (2020). Retrieved January 30, 2020 from https://ua.interfax.com.ua/news/general/638405.html

6. Klymenko, O. (2019a). Involvement of children in armed conflicts: models and methods of recruitment (Ukrainian experience). Sociological Studios, 2(15), 13-20. DOI: https://doi.org/10.29038/2306-3971-2019-0213-20

7. Klymenko, E. (2019b). Die Schwächsten der Schwachen Ukraine: Kinder im Krieg. Osteuropa, 3-4, $185-191$. Retrieved June 10, 2020 from https://www.zeitschrift-osteuropa.de/hefte/2019/3-4/die-schwaechsten-derschwachen/

8. On the protection of childhood: the Law of Ukraine (2001)/Retrieved July 03, 2020 from https://zakon. rada.gov.ua/laws/show/2402-14\#Text

9. On the Role of Gender in Preventing and Combating Violent Extremism and Radicalization that Lead to Terrorism (2016). Retrieved June 18, 2016 from https://www.osce.org/files/f/documents/1/1/429452_0.pdf

10. Ramsay, G. (2013). Jihadi Culture on the World Wide Web. 51-78. https://doi.org/10.5040/9781501301049.ch003. Retrieved October 10, 2020 from https://www.bloomsbury.com/uk/jihadi-culture-on-the-world-wide-web9781441124395/

11. Stop the War on Children. Gender Matters (2020a). Save the Children. Retrieved November 20, 2020 from https://resourcecentre.savethechildren.net/node/16784/pdf/ch1413553.pdf

12. Stop the War on Children. Killed and Maimed: A Generation of Violations Against Children in Conflict (2020b). Save the Children. Retrieved November 20, 2020 from https://resourcecentre.savethechildren.net/node/ 18486/pdf/killed_and_maimed_a_generation_of_violations_final.pdf 
13. The Constitution of Ukraine (1996). Retrieved January 1, 2020 from https://zakon.rada.gov.ua/laws/ show/254k/96-vr\#Text

14. The GPU is investigating the recruitment of children by DPR militants (2019). Retrieved August 12,2019 from https://zn.ua/UKRAINE/gpu-rassleduet-verbovku-detey-boevikami-dnr-326711_.html

15. Zybchenko, S. (2016). Children of War: how Russia is attracting Ukrainian youth from the temporarily occupied territories to terrorist activities. ZN,UA, 15. Retrieved April 22, 2016 from https://zn.ua/internal/deti-voyny-kakrossiya-privlekaet-ukrainskuyu-molodezh-s-vremenno-okkupirovannyh-territoriy-k-terroristicheskoy-

deyatelnosti-_.html 